\title{
Innovation with High Social Benefits and Corporate Financial Performance
}

\author{
Robert C. Padgett', Rosamaria C. Moura-Leite²
}

\begin{abstract}
This article analyzes the effect that innovation with high social benefit has on financial performance, and to improve our understanding of this effect we extend our research by analyzing the effect of being an innovation leader has on financial performance. We intend to give insight about which innovation strategy impacts with more intensity on financial performance. To support this analysis we will make use of the resource-based view theory and the institutional theory. Our research used the panel data technique. The final sample contains 2025 observations for 418 firms. The results of this research demonstrate that there is a negative and significant effect between innovation with high social benefit and financial performance, highlighting the importance of the involvement of governmental and non-governmental institutions to create an incentive for firms to incur in innovative activities that produce social benefits.
\end{abstract}

Keywords: corporate social responsibility; innovation with high social benefits; research and development; resource based view theory; institutional theory.

\footnotetext{
'Role: Member of lbero-American think tank in Management and Corporate Social Responsibility. Department: Business Economics. University/Institution: University of Salamanca.Address: Campus Miguel de Unamuno, Edificio FES, 37007.Town/City: Salamanca. Country: Spain ${ }^{2}$ Role:Visiting professor. Department: Business. University/Institution: Mato Grosso do Sul Federal University.Address: Cidade Universitária. Caixa Postal 549, 79070-900.Town/City: Campo Grande-MS. Country: Brazil
} 


\section{Introduction}

Previous literature has identified several reasons or incentives for firms to incur in Research and Development (R\&D) activities (Coombs and Beirly, 2006; Holmes and Smart, 2009; Wagner, 2010). Given the significant regulatory and non-regulatory pressures on firms to decrease pollution and costs, it is natural to wonder whether innovation is a response to these pressures or to other market forces such as international competition and industry or economy-wide characteristics. It is difficult to determine if firms respond to these pressures by investing in new innovative technologies that might lower the cost of environmental protection. In that regard, the literature to date is sparse (Brunnermeier and Cohen, 2003).A number of empirical studies have attempted to identify such determinants at the level of the firm as well as for aggregated industries (e.g. Brunnermeier and Cohen, 2003; Jaffe and Palmer, 1997; McWilliams and Siegel, 2000; Rennings et al., 2006). For example, McWilliams and Siegel (2000) demonstrate, innovation is a significant driver of firm performance, and when innovation is included among the independent variables the significance of the CSR-financial performance relationship disappears. Also, they prove that CSR is positively correlated with R\&D intensity. Another research by Hull and Rothenberg (2008), corroborate this finding and finally Padgett and Galan (2010) study the relationship between these two variables and found a significant positive relationship.A more recent research Wagner (2010) analyzes the link between innovation with high social benefits and corporate social performance. However, none of these researches have studied the direct impact of innovation with social benefits has on corporate financial performance, so we considered it necessary to study this effect in order to fill this gap in the literature.

This article analyzes the effect that innovation with high social benefit has on financial performance, and to improve our understanding of this effect we extend our research by analyzing the effect that being an innovation leader has on financial performance, with the intention of observing different innovation strategy effects on financial performance. To support this analysis we will make use of the resource-based view theory and the institutional theory. The resource-based view (RBV) theory of strategic management (Barney, 1991; Peteraf, 1993; Wernerfelt, 1984) examines resources and capabilities of firms that enable them to obtain a competitive advantage and above average rates of return. The RBV theory, recognizes the importance of intangible resources, making it ideal to study such variables as corporate social responsibility (CSR) and research and development (R\&D), since they are difficult to imitate and substitute and lead to competitive advantages (Branco and Rodriguez, 2006). Despite the valuable insights of the RBV theory some aspects have not been examined, such as the social context within which resource selection decisions are embedded and how this context might influence sustainable differences (Oliver, 1997; Ginsberg, 1994). According to Oliver (1997), in order to complement the RBV theory and analyze the social context of resources, it is necessary to include the institutional theory (DiMaggio and Powell, 1991; Scott, 1995), which examines the role of social influences and pressures for social conformity in determining organizations' decisions and actions.

By implementing both the RBV theory and the institutional theory as the theoretical framework for this research, we intend to support the intentions of firms to participate in R\&D activities, because firm's innovations (social or not) will produce a differentiation in the market, thus creating a competitive advantage that will generate above normal rates of return and furthermore can create legitimacy which leads to a good reputation.

Our research used a panel data technique, which allowed us to control the risk of unobserved heterogeneity on the manager's conceptions of social responsibility and company strategy (Bouquet and Deutsch, 2008). Our main hypothesis tries to identify if innovation with high social benefit has a positive impact on the financial performance of firms, since firms seek to obtain benefits such as differentiation and higher sales from innovation. Some researchers like Lev, Redhakrishnan and Ciftci (2006) have stated that there is a clear difference in the performance of innovation followers and leaders, which are recognized as having excess returns, because of higher sales growth, and return on assets. Thus, we extend our research by focusing on the performance of innovation leaders, and expect that leaders will always have an above average performance when investing in innovation. This article contributes to the literature because we are studying the effect that innovation with high social benefit has on financial performance, which observes and aids to determine if firms have a financial incentive to incur in innovative activities that produce some kind of social benefits. If there is no financial incentive in the short-term, it should be a sign for governmental and non-governmental institutions to create an incentive for firms that are doing this type of innovative activities. In addition to studying this effect we observe the effect that another innovation strategy as is being an innovation leader has on a firm's financial performance. Furthermore, we combine the RBV and the institutional theory in order to build a theoretical framework that supports researches such as Oliver's (1997). Regarding managerial contributions, our research provides an insight of what firms should expect when participating in innovation with high social benefits. Moreover, we reinforce the importance and benefits of being an innovation leader. 


\section{Theory and hypotheses}

\section{Resource Based View and Institutional Theory}

"A resource based view proposes that resource selection and accumulation are a function of both within-firm decision making and external strategic factors" (Oliver, 1997:698). Whether resource selection and accumulation result in competitive advantages, it will depend upon market imperfections, such as barriers to acquisition, imitation, and substitution of key resources or inputs (Barney, 1991; Penrose, 1959; Schoemaker and Amit, 1994). These barriers create differentiation, allowing the resource holders to achieve competitive advantages over competitors, whose abilities are held back because of their struggle to obtain or duplicate these resources (Barney, 1986; Dierickx and Cool, 1989).

Resources are classified as tangible, intangible, and personnel-based (Grant, 1991). Tangible resources include physical resources such as infrastructure, equipment, raw materials, and financial reserves. Intangible resources include knowhow, reputation and technology. Finally, personnel-based resources involve such concepts as culture, training, commitment, loyalty and knowledge. None of these resources is productive on its own, but a combination of these is what will make the firm productive. (Russo and Fouts, 1997)

According to Russo and Fouts (1997), the RBV theory firm offers corporate social responsibility researchers a tool for refining the analysis of corporate social policies, because it has a strong focus on performance as the key outcome variable and it explicitly recognizes the importance of intangible concepts.Even though the RBV has provided numerous insights, according to Oliver (1997), the RBV theory does not address the process of resource selection, decisions and rational choices about resource selection in order to achieve economic rents. In order to cover these "gaps" in the RBV theory we will include insights from the institutional theory (DiMaggio and Powell, 199I; Scott, 1995) in this research.

Drawing on the institutional perspective, our research will be strengthened by the idea that resource selection and sustainable competitive advantage are profoundly influenced, by the firm's circumstances, such as rules, norms, and beliefs surrounding economic activities that define or enforce socially acceptable economic behaviors taken into account for resource decisions (Oliver, 1997).

Researches based on institutional theory like, Galaskiewicz's (1991) showed that firms tend to act socially responsible when normative or cultural institutions create incentives for such behavior. Also, Beliveau, Cottrill and O'Neil (1994), found that corporate social performance and its relationship with firms' profitability varies by industry. This could be explained because of the "overall profile of the industry in terms of its public visibility and the degree of scrutiny from government and the public it operates under, the competitive structure of the industry, and the overall historically determined culture of the industry" (Jones, 1999:167). CSR is attracting considerable publicity and as a result, CSR has surfaced as an unavoidable priority for business leaders around the world, because it is being recognized as a source of opportunity, innovation, and competitive advantage (Porter and Kramer, 2006).

From the above statements it can be seen that the RBV theory supports the intentions of firms to participate in R\&D activities, because these innovations will produce a differentiation in the market, thus creating a competitive advantage that will generate above normal rates of return. Meanwhile, the institutional theory supports the intentions of firms to participate in R\&D activities because they acquire legitimacy when they attend to stakeholder pressures that call for innovation to reap the benefits of proactive social action (Quazi and O’Brien, 2000).

\section{Innovation with high Social Benefit}

As was mentioned before, several researchers have found a link between CSR and R\&D. For example, McWilliams and Siegel (2000) demonstrate, innovation is a significant driver of firm performance, and when innovation is included among the independent variables the significance of the CSR-financial performance relationship disappears. Also, they prove that CSR is positively correlated with R\&D intensity. Another research by Hull and Rothenberg (2008), corroborate this finding and finally Padgett and Galan (2010) study the relationship between these two variables and found a significant positive relationship.Also, McWilliams and Siegel (200I) research suggests that firms can participate in CSR activities by product or process innovation. They give the example of products that have CSR properties such as pesticide-free fruit or processes such as naturally occurring insect inhibitors and organic fertilizers. These kinds of innovations besides providing a benefit to the company provide certain benefits to society.

A more recent research Wagner (2010) analyzes the link between innovation with high social benefits and corporate social performance. The author describes how firms can do innovation that produces private benefits, such as improved products, creating advantages to the firm. Also, these innovations can produce social benefits, such as process improvements that reduce pollution. The author establishes that innovation should have an equilibrium where companies are encouraged to innovate because they will obtain higher rents and at the same time give something to society. According to Wagner (2010), innovation with high social bene- 
fits can be defined as an innovation that has a positive direct social effect, such as reduced environmental externalities and provision of products or services for the economically disadvantaged.

Rennings (2000), states that essentially it does not matter whether firms pursue innovations with high social benefits for profit or not, although most firms will attempt to achieve profit by pursuing innovation with high social benefit. Scott (1987) observes that organizations "play the game" because they are rewarded for doing so through increased legitimacy, resources and survival capabilities. Firms should see that by innovating with high social benefits firms create differentiation and legitimacy. The basic argument of the RBV theory is that rare, specialized, inimitable resources cause firm heterogeneity, and that successful firms are those that acquire and maintain valuable idiosyncratic resources for sustainable competitive advantage. If firms go one step further and conform to predominant norms, traditions, and social influences in their internal and external environments will gain support and legitimacy, according to the institutional theory (Oliver, 1997) and become successful at least over the long term (Jones, 1995). In addition, firm's legitimacy, leads to obtaining a good reputation (Doh, Howton, Howton and Siegel, 2010). Furthermore there is a mutual dependence between corporations and society which implies that both business decisions and social actions must follow the principle of shared value. Choices must benefit both sides, because if either businesses or society pursue actions that benefit their own interests at the expense of the other, they will find themselves on a risky path, where a momentary gain of one will weaken the long-term prosperity of both (Porter and Kramer, 2006). Based on these insights, the following hypothesis can be stated:

Hypothesis I: Innovation with high social benefit has a positive effect on corporate financial performance.

\section{Innovation Leaders}

According to Porter (1985) firms strategically choose to be innovation leaders or followers: some R\&D firms are leaders who introduce new and innovative products while others are followers who mimic or react to the products of the leaders. It is common-place for industry leaders to devote substantial resources for innovation because of several reasons, one being that industry leaders have a small $R \& D$ cost advantage (Segerstrom and Zolnierek, 1999). In addition, firms tend to view innovation leadership mainly as a vehicle for achieving differentiation, while being a follower is considered an approach to achieving low cost, thus, the decision of being a leader or a follower is based on sustainability of the technological lead, first mover advantages and first mover disadvantages (Porter, 1985).
The competitive advantage that leaders have may come from a variety of sources, such as lower cost, better products and services, faster innovation, strong distribution channels, and financial strength, meanwhile followers lack some of the advantages that leaders have (Ito and Pucik, 1993). These resources cause leaders to differentiate themselves from followers, and it is difficult for followers to achieve competitive advantage because the resources that leaders possess are usually rare and difficult to replicate, allowing them to sustain a superior financial performance (Barney, 1991; Grant, 1991; Roberts and Dowling, 2002). Furthermore, the RBV assumes that resources and capabilities provide firms with a competitive advantage that allows them to pursue opportunities or avoid threats (Barney, 1991), thus allowing leaders to stay ahead of their competitors.Additionally, intangible resources such as R\&D and innovation have been traditionally perceived to be the basis of a firm's competitive advantage (Barney, 199I; Dierickx and Cool, 1989; Wernerfelt, 1984).

According to Lev, Redhakrishnan and Ciftci (2006), there is a clear difference between innovation leaders and followers, since leaders earn significant excess returns, while innovation followers just earn average returns. Moreover, innovation leaders generate higher sales growth and return-onassets than followers. Other researches support the view that innovation leaders obtain better results than followers, like the research done by Ito and Pucik (1993), found that market leaders have advantages over followers, due to two reasons: first, for industry leaders, the risk-adjusted returns may be better because leaders have already built competitive advantages in finance, marketing, etc. Second, competitive advantage can be more profitably leveraged through horizontal or vertical differentiation. Also, Caves and Ghemawat (1992) research, which examines the factors that sustain profit differentials across firms within an industry, found that differentiation related strategies such as R\&D, play a more important role than cost related strategies.

As we mentioned before, differentiation related strategies are indicative of innovative leadership, such as, new products/ services, while cost related strategies are more related with innovative follower behavior.Another research that supports this argument is Klette (1996), which shows that innovation could help improve future profitability due to knowledgespillovers across lines of business: innovation could have a lasting impact on performance due to knowledge-spillovers. In addition, Zahra and Covin (1993) provide evidence that suggests that high-performing companies adopt a coherent set of technological choices that, taken together, create a competitive advantage, especially in mature sectors where technology plays a prominent role. Finally, Gruber (1992) shows that in a vertically differentiated product market where fixed costs of innovation decline overtime innovation leaders are persistent in their performance. 
Considering the arguments regarding the differences between innovation leaders and followers and why leaders have an advantage, we state the following hypothesis:

Hypothesis 2: Being an innovation leader positively impacts on corporate financial performance.

\section{Methods}

\section{Sample and data}

The data was obtained from two databases:Worldscope database and Kinder Lydenburg Domini (KLD) social rating data. KLD database is a reliable source for CSR measures and has been widely used by previous researchers (see Orlitzky et al., 2003; Margolis et al., 2007;Wood, 20I0). It comprises numerical assessments on thirteen categories. Seven of those relate to social responsibility qualitative issues' areas and the remaining six to engagement in controversial business. For the first set of dimensions, there is a subset of items regarded as strengths and concerns. The qualitative issues are: product issues; community relations; environmental issues; human rights; governance; employees' relations and diversity of the work force. The rating is a binary system, where $I$ indicates the presence of this item and 0 its absence. Previous researchers have tailored this rating system for their own objectives. From this database we extracted the CSR measure and also innovation with high social impact and leaders in innovation proxy, we give more detail about this proxy later.

The sample composed of US firms is unbalanced and covers a twelve-year period from 1996 to 2007. The sample was screened in various ways as firms' innovation is strongly determined by its sectors' characteristics. We excluded firms that did not contain a primary SIC designation, and defined firms' sectors by their two-digit SIC identification code. We also discarded sectors that have less than 10 observations each year and sectors that have no firms that present innovation with high social benefit. The final sample contains 2025 observations for 418 firms across 7 sectors (Food and Kindred Products; Chemicals and Allied Products; Fabricated Metal Products; Industrial and Commercial Machinery and Computer Equipment; Electronic and Other Electrical Equipment and Components; Transportation Equipment; Measuring, Analyzing and Controlling Instruments, Photographic, Medical and Goods, Watches and Clocks).

\section{Measures}

For measuring our dependent variable (CFP) we follow the recent CSR literature and adopted market-based measure (e.g. Bird et al., 2007; Kacperczyk, 2009; Surroca et al., 2010). We decided to use Tobin's q, mainly because of its ability to capture the value of long-term investments like innovation investments as explained by Dowell, Hart and Yeung (2000). Tobin's q reflects the ratio between the firm's market value and its replacement value of capital. It is calculated by dividing the market value of a company by the replacement value of its book equity.

To measure innovation with high social benefits we follow Wagner (2010) and construct a proxy for it using three useful variables of the KLD database, those that are related with firms' innovation. The first variable is taken from by the strength environment issue qualitative area, called ENV-str$A$ by KLD, and this variable indicates that a firm has newly introduced products or services which protect the environment or is achieving significant sales with such innovative products or services because of its concern with protecting the environment. The second and third are taken from by the strength product issue qualitative area, the KLD database respectively names them as PRO-str-X and PRO-str-C. PRO-str-X measure whether a firm's products have notable social benefits that are highly unusual or unique for its industry and PRO-str-C records whether part of a firm's mission is the provision of products or services for the economically disadvantaged. These three variables are binary and assume value $I$ if the firms have this characteristic and 0 when they do not. Our variable innovation with high social benefits is the sum of these three variables. Furthermore, as proxy innovation leader we also used a KLD binary variable that was taken from the strength product issue qualitative area and is called PRO-str-B in KLD database. This variable indicates that a firm is a leader in its industry for R\&D, particularly by bringing notably innovative products to market.

We have used control variables based on the degree to which they may influence the effect that innovation with high social benefit and innovation leader have on CFP. McWilliams and Siegel (2000) show that investment in R\&D is positively correlated with CSR and CFP, which can be explained by the fact that some innovations result from investments in R\&D generate advantages for society (McWilliams and Siegel, 2000; Padgett and Galan, 20I0), however not all R\&D investment generates social benefit. Thus is important to control R\&D intensity to understand the effect of innovation with high social benefit and the innovation leader on CFP.To measure this, we use a proxy of R\&D, calculated by dividing total expenditure in R\&D by total number of employees. This ratio is "less sensitive to the spurious effects of business cycles, accounting manipulations, and asset sales than R\&D spending as a proportion of sales" (Baysinger, Kosnik and Turk, |99|:207), and is positively related to patents and product innovations (Hitt, Hoskisson and Kim, 1997).

Therefore, for the purpose of this research it is also necessary to control the firms' overall social responsibility index.

ISSN: 07 I8-2724. (http://www.jotmi.org)

Journal of Technology Management \& Innovation (C) Universidad Alberto Hurtado, Facultad de Economía y Negocios. 
We used the five KLD dimensions consistently reported between 1996 and 2007: product issues; community relations; environmental issues; employees' relations and diversity of the work force. These dimensions have been selected because they reflect corporate attention to primary stakeholders with an impact on a firm's survival (Clarkson, 1995) and exert considerable influence on corporate strategy (Berman,Wicks, Kotha, and Jones, 1999). We develop the same scale used by Hillman and Keim (200I), which is also used by other authors (e.g.Hull and Rothenberg, 2008). All of the strengths of each dimension are rated on a scale ranging from 0 to +2 , in the same way all concerns of each dimension are rated from -2 to 0 . Then, we add the strengths scale plus the concerns scale of each dimension, having as a result a scale ranging from -2 to +2 . We build the corporate social responsibility measure giving equal weights to the five dimensions cited above (Hillman and Keim, 200I).

In line with McWilliams and Siegel (2000) who posit importance on the nature of a firm's industry on its innovation and social responsibility, we control industry effect using twodigit SIC sector dummy variables. In addition, we also adopt as control variable a measure of company size, because previous articles have suggested it is closely related to CFP (e.g. Udayasankar, 2008;Waddock and Graves, 1997), and we measure it as the total asset (e.g. Griffin and Mahon, 1997; Hull and Rothenberg, 2008), defined on a log scale. Risk is another factor used as a control variable; we have adopted $\beta$ (beta) - a standard indicator of market-based risk (Hillman and Keim, 200I).

\section{Results}

Assuming the long-term effect of innovation and social actions have on CFP, we have estimated our models with a one-year lag on innovation leader, innovation with high so- cial benefits, the independent variables, and also on R\&D intensity and corporate social responsibility control variables. We have also estimated our models with a two-year lag on these variables and found a similar result. We have used the panel data technique to estimate our model. Unlike crosssectional analysis, panel data allows us to control every firm. Our models were initially specified using the fixed effect estimator. We carried out a Hausman test that indicated correlation between individual effects and independent variables. In the light of this, the fixed effect is best suited than the between effects. As well as the individual effects added to control for the cross- reference units, we have also included time dummies in our model. With these temporal effects we reduce a source of bias by capturing the events that all states were subjected to in a given year. An F test of significance was performed to assert the joint significance of the temporal dummies and the result was that they contribute to the model overall's significance. We have also applied the Wooldridge and Modified Wald tests to examine potential autocorrelation in our panel and heteroskedasticity problems in our fixed effect equation. In all cases the results were positive. Consistent with Beck and Katz (1995), we have corrected both problems using panel corrected standard errors through a Prais-Winsten regression.

Table I provides descriptive statistics and correlation matrices for the variables. To test for multicollinearity, we checked the correlation matrix and variance inflation factors (VIFs) of the regression models on both pooled data and individual years of data. We found that allVIFs were smaller than 3. On table I we can observe that CFP has a negative significant correlation with Innovation with high social benefit, along with a positive significant correlation with innovation leader. We can also see, that R\&D intensity has a positive significant correlation with innovation leader, although has a negative significant correlation with Innovation with high social ben-

\begin{tabular}{|c|c|c|c|c|c|c|c|c|c|}
\hline & \multirow{2}{*}{ Variable } & \multirow{2}{*}{ Mean } & \multirow{2}{*}{ S.D. } & \multicolumn{6}{|c|}{ Correlations } \\
\hline & & & & 1 & 2 & 3 & 4 & 5 & 6 \\
\hline 1 & Tobin's q & 2.29 & 1.82 & & & & & & \\
\hline 2 & $\begin{array}{l}\text { Innovation with high } \\
\text { social benefit }\end{array}$ & $\mid 0.09$ & 0.28 & $-0.07^{* *}$ & & & & & \\
\hline 3 & $\begin{array}{l}\text { Industry innovation } \\
\text { leader }\end{array}$ & 0.08 & 0.28 & $0.10 * *$ & $0.08^{* *}$ & & & & \\
\hline 4 & R\&D intensity & 25.09 & 36.53 & $0.29 * *$ & $-0.11 * *$ & $0.04 *$ & & & \\
\hline 5 & CSR & 0.28 & 0.59 & $0.14 * *$ & $0.21 * *$ & $0.27 * *$ & $0.06 * *$ & & \\
\hline 6 & Risk & 1.12 & 0.47 & $-0.24 * *$ & -0.02 & $-0.04 *$ & $-0.17 * *$ & $-0.11 * *$ & \\
\hline 7 & Size & 14.73 & 1.62 & $-0.09 * *$ & $0.06^{* *}$ & $0.11 * *$ & $-0.08^{* *}$ & $0.28 * *$ & -0.01 \\
\hline
\end{tabular}

Table I. Descriptive statistics and Correlations matrix a

ISSN: 07I 8-2724. (http://www.jotmi.org)

Journal of Technology Management \& Innovation (C) Universidad Alberto Hurtado, Facultad de Economía y Negocios. 
efit, as predicted by the literature, that the high R\&D intensity not compulsory generate social benefit. Furthermore, the overall CSR proxy is significant and positively correlates to all our models variables, except with risk which has a significant and negative correlation.

Table two shows the three models we developed in our research. Our first model shows the effect that the control variables have on our dependent variable, corporate financial performance, our second model reflects the effect that innovation with high social benefit has on the corporate financial performance of the firm and our third model reflects the effect that being an innovation leader has on corporate financial performance of the firm. The results of the regression analyses provide support to reject Hypothesis I, as they indicate that innovation with high social impact has a negative effect on financial performance $(p<0.0 \mathrm{I})$. On the other hand, Hypothesis 2 is supported, since we found that innovation leader has a positive effect on financial performance $(p<0.10)$. We controlled for R\&D intensity, CSR, firm risk, firm size and industry. The results show that R\&D intensity is significant and positively associated with CFP $(p<0.01)$ in all models, furthermore CSR overall proxy is significant and positively associated with CFP $(p<0.05)$ in our first and second model, and at $(p<0.1)$ in our third model. In addition the control variables firm risk and size are both significant and negatively associated to CFP $(P<0.05)$ in all models.

\section{Discussion and conclusion}

As we mentioned before, this article has the objective of analyzing the effect that innovations with high social benefits have on financial performance, and to enhance the understanding of this effect we extend our research by analyzing the relationship between being an innovation leader and financial performance, with the intention of observing the behaviour of different innovation strategy effects on corporate financial performance.

To establish our theoretical framework, we combined the RBV theory with the institutional theory which allowed us to analyze resource selection and accumulation, looking at market imperfections, such as barriers to acquisition, imitation, and substitution of key resources or inputs (Barney, 1991; Penrose, 1959; Schoemaker and Amit, 1994), and the social context within which resource selection decisions are embedded, such as firm tradition and regulation pressures, and how this context might influence sustainable differences (Oliver, 1997; Ginsberg, 1994). Drawing on both theories in our research, strengthened the idea that resource selection and sustainable competitive advantage are profoundly

\begin{tabular}{|l|l|l|l|}
\hline & 01 & 02 & 03 \\
\hline Innovation with high social benefit & & $\begin{array}{l}-0.3474^{* *} \\
(0.1080)\end{array}$ & \\
\hline Industry innovation leader & & & $\begin{array}{l}0.3494 \dagger \\
(0.2123)\end{array}$ \\
\hline R\&D intensity & $\begin{array}{l}0.0086^{* *} \\
(0.0019)\end{array}$ & $\begin{array}{l}0.0083^{* *} \\
(0.0019)\end{array}$ & $\begin{array}{l}0.0086^{* *} \\
(0.0019)\end{array}$ \\
\hline CSR & $\begin{array}{l}0.1857^{* *} \\
(0.0700)\end{array}$ & $\begin{array}{l}0.2093^{* *} \\
(0.0719)\end{array}$ & $\begin{array}{l}0.1566^{*} \\
(0.0723)\end{array}$ \\
\hline Risk & $-0.5143^{* *}$ & $\begin{array}{l}-0.5128^{* *} \\
(0.1102)\end{array}$ & $\begin{array}{l}-0.5073^{* *} \\
(0.1098)\end{array}$ \\
\hline Size & $(0.1098)$ & $\begin{array}{l}-0.1668^{* *} \\
(0.0369)\end{array}$ & $\begin{array}{l}-0.1723^{* *} \\
(0.0376)\end{array}$ \\
\hline Constant & $-0.1676^{* *}$ & $\begin{array}{l}5.0388^{* *} \\
(0.6332)\end{array}$ & $(0.6412)$ \\
\hline Wald chi2 & $(0.0369)$ & 320.18 & 316.98 \\
\hline R2 & $\begin{array}{l}5.0303^{* *} \\
(0.6326)\end{array}$ & 0.2559 & 0.2558 \\
\hline
\end{tabular}

Table 2. Results of Regression Analyses. Regression coefficients are shown in the table. Standard deviations are in parentheses Estimation also includes dummy for the years (1997-2007) and for industry.

ISSN: 07 I 8-2724. (http://www.jotmi.org)

Journal of Technology Management \& Innovation (C) Universidad Alberto Hurtado, Facultad de Economía y Negocios. 
influenced, by the firm's circumstances, such as rules, norms, and beliefs surrounding economic activities that define or enforce socially acceptable economic behaviors taken into account for resource decisions (Oliver, 1997).

The results of this research demonstrates that innovation with high social benefit has a negative effect on financial performance, which provides support to reject our first hypothesis that states that there is a positive effect between these two variables. Even though, innovation with high social benefit does not impact positively on financial performance, we assume based on Doh, et al. (2010) that it can generate legitimacy which leads to good reputation.

According to Godfrey (2005), reputation in and of itself has no cash value, but it may generate economic value in the long term. This suggests that firms that are performing this type of innovations are not obtaining immediate financial benefits. This is a sign for Governmental and Non-governmental institutions so that they can provide incentives to firms so that they continue performing this kind of innovations that provide benefits towards society and in the long run obtain financial profit. Further research could be done on this topic to determine which kind of innovations with social benefit do have positive financial returns on a shorter term, like Hart and Ahuja (1996) have found when studying the reduction of emissions and firm performance, where they determined that it does pay to be green and innovate to reduce emissions. Also, King and Lennox (200I), found that lower pollution has a positive effect on higher financial valuation but this result depends on firm's fixed characteristics and strategic position, and propose that instead of asking the question "Does it pay to be green? is a less important question than When does it pay to be green?". Furthermore, other researchers have argued that it is important for firms to look beyond their narrow focus of social responsibility and take social concern into consideration in strategic management decisions, since social actions will ensure business interests in the long term by creating a close relationship with their community (Quazi and O'Brien, 2000).

Furthermore, our results demonstrated that being an innovation leader does have a positive impact on financial performance, in line with Lev, et.al. (2006). As Barney (1991), Grant (199I) and Roberts and Dowling (2002) have stated, resources cause leaders to differentiate themselves from followers, and it is difficult for followers to achieve competitive advantage because the resources that leaders possess are usually rare and difficult to replicate, allowing them to sustain a superior financial performance.

The academic value of this research is that it has provided a greater understanding of this subject, since to our knowledge there has been no other study that focuses on the effect that innovation with high social benefit and innovation leadership has on financial performance, which observes and aids to determine if firms have a financial incentive to incur in innovative activities that produce some kind of social benefits. Since, there is no financial incentive in the short-term, it should be a sign for governmental and non-governmental institutions to create an incentive for firms that are doing this type of innovative activities. In addition, our model was estimated using panel data techniques, which are better capable of controlling for inherent heterogeneity than a simple regression. Also, our research opens other research questions, such as: which activities under innovation with high social benefit can be profitable to the firm in the short term, what circumstances and characteristics the firms need to posses in order to obtain a profit from this type of activities. Regarding managerial value, this study provides information to firms, about what to expect when doing innovation with high social benefit. As we have mentioned before, even though the relationship between these two variables is negative, probably there are other benefits that can be obtained from innovation with high social benefit, which fosters future research. Some of the benefits obtained in the long run from innovation with social benefit may create legitimacy when attending to stakeholders demand for innovative actions that provide a benefit to society. Furthermore, there is a positive relationship between being an innovation leader and financial performance, which might encourage firms to become innovation leaders in order to obtain a competitive advantage. Finally, our results demonstrated that in a short period of time, being a leader in innovation has a better impact on financial performance than having innovation with high social benefit.

\section{References}

BARNEY J. (1986). Organizational culture: can it be a source of sustained competitive advantage? Academy of Management Review, II, 656-665.

BARNEY J. (1991). Firm resources and sustained competitive advantage. Journal of Management, I7, 99-I20.

BAYSINGER B. D., Kosnik R. D. and Turk T. A. (I99|). Effects of board and ownership structure on corporate R\&D strategy.Academy of Management Journal, 34 (I), 205-2I 4.

BECK, N. and Katz, J. N. (1995). What to do (and not to do) with Time-Series Cross-Section Data.American Political Science Review, 89 (3), 634-647.

BeLIVEAU, B., Cottrill, M. and O'Neill H. M. (1994). Predicting Corporate Social Responsiveness:A Model Drawn from Three Perspectives. Journal of Business Ethics, 13 (9), 73I738. 
BERMAN, S. L., Wicks, A. C, Kotha, S and Jones, M.T. (1999). Does stakeholder orientation matter? The relationship between stakeholder management models and firm financial performance. Academy of Management Journal, 42 (5) 488506.

BIRD, R., Hall,A. D., Momente, F. and Reggiani, F. (2007).What Corporate Social Responsibility Activities are Valued by the Market? Journal of Business Ethics, 76, 189-206

BOUQUET, C. and Deutsch,Y. (2008). The Impact of Corporate Social Performance on a Firm's Multinationality. Journal of Business Ethics, 80, 755-769.

BRANCO, M.C. and Rodrigues, L.L. (2006). Corporate social responsibility and resource-based perspectives. Journal of Business Ethics, 69, III-I32.

BRUNNERMEIER, S. B. and M. A. Cohen (2003). Determinants of Environmental Innovations in US Manufacturing Industries. Journal of Environmental Economics \& Management, 45, 278-293.

CAVES, B. E. and Ghemawat, P. (1992). Identifying mobility barriers. Strategic Management Journal, I3, I-I2.

CLARKSON, M. (1995). A stakeholder framework for analyzing and evaluating corporate social performance. Academy of Management Review, 20, 92-I I7.

COOMBS, J. E. and Bierly, P. E. (2006). Measuring technological capability and performance. R\&D Management, 36 (4), 42 I-458.

DIERICKX, I., and Cool, K. (1989). Asset stock accumulation and sustainability of competitive advantage. Management Science, 35 (I2), I504-I5II.

DIMAGGIO, P. J. and Powell,W.W. (1983). The iron cage revisited: Institutional isomorphism and collective rationality in organizational fields. American Sociological Review, 48, I47-160

DOH J. P., Howton, S. D, Howton, S. W, Siegel, D. S. (2010). Does the Market Respond to Endorsement of Social Responsibility? The Role of Institutions, Information, and Legitimacy. Journal of Management, 36, I 46 I-I 485

DOWELL, G., Hart, S. and Yeung, B. (2000). Do corporate global environmental standards create or destroy market value? Management Science, 46 (8), 1059-1074.

GALASKIEWICZ, J. (199I). Making corporate actors accountable: Institution-building in Minneapolis-St. Paul'. In W.
W. Powell \& P.J. DiMaggio (Eds.), The new institutionalism in organizational analysis; 293-310. Chicago: University of Chicago Press.

GINSBERG, A. (1994). Minding the competition: From mapping to mastery', Strategic Management Journal, I5, I53-I74.

GODFREY, P.C. (2005). The relationship between corporate philanthropy and shareholder wealth: A risk management perspective. Academy of Management Review, 30, 777-798.

GRANT, R. M. (|99|). The resource-based theory of competitive advantage: implications for strategy formulation. California Management Review, Spring, I I 4-135.

GRIFFIN, J. and Mahon, J. (1997). The corporate social performance and corporate financial performance debate: 25 years of incomparable research. Business and Society, 36, 5-31.

GRUBER, H. (1992). Persistence of Leadership in Product Innovation. The Journal of Industrial Economics, 40 (4), 359375

HART, S. L. and Ahuja, G. (1996). Does it pay to be green? An empirical examination of the relationship between Emission Reduction and FirnPerformance. Business Strategy and the Environment, 5, 30-37.

HILLMAN, A. J. and Keim, G. D. (200I). Shareholder Value, Stakeholder Management, and Social Issues:What's The Bottom Line? Strategic Management Journal, 22, I25-139.

HITT, M.A., Hoskisson, R. E. and Kim, H. (1997). International diversification: effects on innovation and firm performance in product-diversified firms. Academy of Management Journal, 40 (4), 767-798.

HOLMES, S. and Smart, P. (2009). Exploring open innovation practice in firm-nonprofit engagements: a corporate social responsibility perspective. R\&D Management, 39 (4), 394409.

HULL, C. E. and Rothenberg, S. (2008). Firm performance: the interactions of corporate social performance with innovation and industry differentiation. Strategic Management Journal, 29, 78I-789

ITO, K. and Pucik, V. ( I993). R\&D Spending, Domestic Competition, and Export Performance of Japanese Manufacturing Firms. Strategic Management Journal, I 4 (I), 6I-75.

JAFFE, A. and Palmer, K. (1997). Environmental Regulation and Innovation: A Panel Data Study. Review of Economics and Statistics, 79 (4), 610-619.

ISSN: 07 I8-2724. (http://www.jotmi.org)

Journal of Technology Management \& Innovation (C) Universidad Alberto Hurtado, Facultad de Economía y Negocios. 
JONES, T. M. (1995). Instrumental Stakeholder Theory: A Synthesis of Ethics and Economics.Academy of Management Review, 404-437.

JONES, M.T. (1999). The Institutional Determinants of Social Responsibility. Journal of Business Ethics, 20, I63-I79.

KACPERCZYK, A. (2009). With Greater Power Comes Greater Responsibility? Takeover Protection and Corporate Attention to Stakeholders. Strategic Management Journal, $30,26 \mid-285$.

KING, A. A. and Lennox, M. J. (200I). Does it really pay to be green? An empirical study of Firm Environmental and Financial Performance. Journal of Industrial Ecology, 5 (I), 105-II6.

KLETTE, T. J. ( 1996). R\&D, scope economies and plant performance. RAND Journal of Economics, 27, 502-523.

LEV, B. I., Radhakrishnan, S. and Ciftci, M. (2006) The Stock Market Valuation of R\&D Leaders', NYUWorking Paper No.

BARUCH LEV-I5. http://ssrn.com/abstract $=1280696$ [Accessed February 06, 20I I].

MARGOLIS, J.D., Elfenbein, H.A. and Walsh, J.P. (2007). Does it pay to be good? A meta-analysis and redirection of research on the relationship between corporate social and financial performance'. Presentation at the Academy of Management Meetings, Philadelphia, PA, August.

MCWILLIAMS,A. and Siegel D. (2000). Corporate social responsibility and financial performance: Correlation or misspecification? Strategic Management Journal, 21, 603-609.

MCWILLIAMS, A. and Siegel D. S. (200I). Corporate social responsibility: a theory of the firm perspective. The Academy of Management Review, 26 (I), I I 7-127.

OLIVER, C. ( 1 997). Sustainable competitive advantage: Combining institutional and resource based views. Strategic Management Journal, 18 (9), 697-7I3.

ORLITZKY, M., Schmidt F. L., Rynes S. L. (2003). Corporate Social and Financial Performance:A Meta-analysis. Organization Studies, 24 (3), 403-44I.

PADGETT, R. C. and Galan, J. I. (20I0). The Effect of R\&D Intensity on Corporate Social Responsibility. Journal of Business Ethics, 93, 407-4I8.

PENROSE, E. (1959). The theory of the growth of the firm. New York:Wiley.
PETERAF, M.A. (1993). The Cornerstones of Competitive Advantage: A Resource-Based View. Strategic Management Journal, I4 (3), |79-191.

PORTER, M. E. (I985). Competitive Advantage, New York, Free Press.

PORTER, M. E. and Kramer, M. R. (2006). The link between competitive advantage and corporate social responsibility. Harvard Business Review, December, I-I5.

QUAZI, A. and O'Brien, D. (2000). An Empirical Test of a Cross-national Model of Corporate Social Responsibility. Journal of Business Ethics, 25, 33 - 5I.

RENNINGS, K. (2000). Redefining Innovation - Eco-Innovation Research and the Contribution from Ecological Economics. Ecological Economics, 32, 319-332.

RENNINGS, K., Ziegler, A. Ankele, K. and Hoffmann, E. (2006). The Influence of Different Characteristics of the EU Environmental Management and Auditing Scheme on Technical Environmental Innovations and Economic Performance. Ecological Economics, 57, 45-59.

ROBERTS, P.W. and Dowling, G.R. (2002). Corporate reputation and sustained superior financial performance. Strategic Management Journal, 23, 1077-1093.

RUSSO, M. V. and Fouts, P. A. (1997). A Resource Based Perspective on Corporate Environmental Performance and Profitability. Academy of Management Journal, 40 (3), 534559.

SEGERSTROM, P. S. and Zolnierek, J. M. (1999). The R\&D Incentives of Industry Leaders'. International Economic Review, 40 (3), 745-766.

SCHOEMAKER, P. J. H. and Amit, R. H. ( I 994). Investment in strategic assets: Industry and firm-level perspectives'. In P. Shrivastava,A. Huff and J. Dutton (eds.),Advances in Strategic Management, I0. JAI Press, Greenwich, CT, 3-33.

SCOTT,W. R. ( 1987). The Adolescence of Institutional Theory.Administrative Science Quarterly, 32 (4), 493-5I I.

SCOTT, W. R. (1995). Institutions and Organizations, Sage, Thousand Oaks, CA

SURROCA, J., Tribó, J.A., and Waddock, S. (2010). Corporate responsibility and financial performance: the role of intangible resource'. Strategic Management Journal. 3 I (5), 463-490.

ISSN: 07 I8-2724. (http://www.jotmi.org)

Journal of Technology Management \& Innovation (C) Universidad Alberto Hurtado, Facultad de Economía y Negocios. 
UDAYASANKAR, K. (2008). Corporate social responsibility and firm size. Journal of Business Ethics, 83, 167- 175.

WADDOCK S. and Graves S. (1997). The corporate social performance-financial performance link. Strategic Management Journal, I8 (4), 303-319.

WAGNER, M. (2010) Corporate Social Performance and Innovation with High Social Benefits: A Quantitative Analysis. Journal of Business Ethics. 94 (4), 58I-594.

WERNERFELT, B. (1984), A resource-based view of the firm. Strategic Management Journal, 5(2), I7|- $\mid 80$.

WOOD, D. J. (2010). Measuring Corporate Social Performance Review. International Journal of Management Reviews. On line (DOI: I0. I I I/j. I 468-2370.2009.00274.x)

ZAHRA, S.A. and Covin, J. G. (1993). Business strategy, technology policy and firm performance. Strategic Management Journal, I4, 45 I-478. 